\title{
Correction to: Does climate-smart village approach influence gender equality in farming households? A case of two contrasting ecologies in India
}

\author{
Vinod K. Hariharan ${ }^{1}$ - Surabhi Mittal ${ }^{1} \cdot$ Munmun Rai $^{1} \cdot$ Tripti Agarwal $^{1}$ • \\ Kailash C. Kalvaniya ${ }^{1} \cdot$ Clare M. Stirling $^{2} \cdot$ M. L. Jat ${ }^{1}$
}

Published online: 15 March 2019

(C) The Author(s) 2019

\section{Correction to: Climatic Change \\ https://doi.org/10.1007/s10584-018-2321-0}

The original article has been corrected. The copyright holder has been update to (C) The Author(s) and the article is now published with open access.

Publisher's note Springer Nature remains neutral with regard to jurisdictional claims in published maps and institutional affiliations.

The online version of the original article can be found at https://doi.org/10.1007/s10584-018-2321-0

\section{L. Jat \\ M.Jat@cgiar.org}

1 International Maize and Wheat Improvement Center (CIMMYT), NASC Complex, New Delhi, India

2 International Maize and Wheat Improvement Center (CIMMYT), Texcoco, Mexico 